\title{
How Nigeria's 2015 Presidential Election Outcome was Forecasted with Geodemographics and Public Sentiment Analytics
}

\section{Adegbola Ojo*}

School of Geography, University of Lincoln. Brayford Pool, Lincoln, Lincolnshire. LN6 7TS,

United Kingdom

Email: AOjo@lincoln.ac.uk

ORCiD: rcid.org/0000-0003-3480-5619

*Corresponding author

Samuel Chukwuemeka Ibeh

Neo-Telligence, 188 Liscard Road, Liscard, Merseyside, CH44 5TN, United Kingdom.

David Kieghe

Neo-Telligence, 188 Liscard Road, Liscard, Merseyside, CH44 5TN, United Kingdom. 


\title{
How Nigeria's 2015 Presidential Election Outcome was Forecasted with Geodemographics and Public Sentiment Analytics
}

\begin{abstract}
In 2015, Nigeria held one of the most fiercely contested presidential elections in the. In 2015, Nigeria held one of the most fiercely contested presidential elections in the nation's recent democratic history. The outcome of the election was expected to exert significant influence on democratic practices on the African continent. The stiffness of the contest also meant that it was difficult to predict the likely winner of the election. This paper summarizes how an empirical approach was used to forecast the outcome of the election by modeling public sentiment dataset using a geodemographic framework. Results indicate that the main electorates that determined the outcome of the election were situated in thirteen battleground states. Additionally, results showed that two years before the presidential election, Goodluck Jonathan's public approval ratings on corruption, insecurity, and the economy (the main drivers of the 2015 election) had nose-dived across many of the battleground states. This eventually contributed toward his loss.
\end{abstract}

Keywords: Geodemographics; Nigeria; Public sentiment analysis; Presidential election; Geographic Information Science; Forecasting 


\section{Introduction}

Although there were irregularities during the Nigerian 2011 presidential election (Uduma and Emerole 2015), it was generally considered credible when compared to some previous elections. Goodluck Jonathan, the People’s Democratic Party (PDP) candidate, benefitted from the public sympathetic support and a weak opposition which ensured he won the election (Adibe 2015). Over 5 in 10 electorates voted for the PDP in 2011 (Lunn and Harari 2014). The other two main contenders were Muhammadu Buhari of the Congress for Progressive Change (CPC) and Nuhu Ribadu of the Action Congress of Nigeria (ACN). Just over 3 in 10 voters supported Buhari whilst Ribadu received approximately 1 in 10 votes (Lunn and Harari 2014). Other political parties including the All Nigeria's Peoples Party (ANPP) shared the rest of the votes.

In February 2013, the All Progressives Congress (APC) was formed following the merger of three core opposition parties - the ACN, the CPC and the ANPP (BBC 2013). A faction of the All Progressives Grand Alliance (APGA) also joined the alliance (Premium Times 2013).

The 2015 presidential election was contested between Goodluck Jonathan of the PDP and Muhammadu Buhari of the APC. Many of independent polls examined voting intentions at geo-political (6 regions) and national scales even though there was a sense that the contest would be stiff in selected states. Better understanding was required at a more granular geographical scale. There are 774 Local Government Areas (LGAs) in Nigeria (Ojo et al. 2012). However, the Nigerian Independent National Electoral Commission (INEC) hardly releases electoral statistics at the LGA scale and this makes it difficult for researchers to attempt local level analysis and forecasts of democratic 
processes. Most studies restrict their analysis to the six geo-political regions or at best the 37 territories that make up states and the Federal Capital Territory (FCT). To the best of our knowledge, no recent national study has successfully profiled critical dimensions of Nigeria’s electoral geography at the LGA scale.

The remainder of this article summarises the profiling of Nigeria's electoral dynamics prior to the 2015 presidential election. The article also explains how the outcome of the election was predicted using insights from secondary data modelling. The article starts by delineating those battleground states where the 2015 election was expected to be fought, won or lost. Next, the implication of multiple registrations during elections is reviewed. This is followed by a discussion on the geography of change in the number of registered voters between 2011 and 2015. This article also examines spatial patterns of voter apathy and discusses the geographical distribution of undecided or floating voters prior to the 2015 presidential election. The focus of the article then shifts towards the political temperature within and between battleground states midway into Goodluck Jonathan's tenure in office. The article concludes by evaluating the probabilities that adults in the battleground states were prepared to vote against former president Goodluck Jonathan.

\section{Data and Methods}

Until the 2015 general election, mainstream political parties in Nigeria did not consider using differential strategic and operational target marketing during their campaign processes (Ibekwe 2015). However, following the emergence of a formidable opposition (the APC) and an increasingly enlightened body of electorates, political parties now recognise the need to proficiently decode the expectations of electorates, match their manifestos to these expectations and effectively communicate their plans in 
an appealing manner (Said-Moorhouse 2015; Bartlett et al. 2015). To achieve these objectives especially in battleground states where the race can be tight, it is essential that a high level of local spatial awareness is adopted by political parties (Carty and Eagles 1999).

Two large secondary datasets underpin the discussion in this paper. The first dataset is a multi-criteria hierarchical geodemographic classification system developed for all LGAs in Nigeria. The Nigerian LGA Geodemographic Classification System (NIGECS) is an area classification that simplifies a large and complex body of information about people, where and how they live (including their lifestyles) and work (Ojo et al. 2012). The methodology used to develop NIGECS is underpinned by geographical theories that people with similar characteristics are more likely to live within the same locality and that such locality types will be distributed in different locations across geographical space (Tobler 1970; Vickers and Rees 2006; Ojo et al. 2013). Table 1 illustrates the structure of the NIGECS.

[Table 1 about here]

Green Towns concentrate mostly in the South Western corner of Nigeria. They tend to be comprised of residents in older age categories with pensioners. Emerging Localities encapsulate 166 LGAs mainly in the North East and are characterised by below average population densities. Intermediate Territories can mostly be found within the South East whilst Diluted Societies concentrate in the North Central Area of Nigeria. Country Dwellings spread across the North East and North Western parts of Nigeria with a mean household size of 5.1 persons and an average population density of 144 persons per square kilometre. Urban Nodes are scattered across the country and do 
not necessarily concentrate in any geopolitical zone. However, the North East has the lowest share of Urban Nodes.

The second dataset is a face-to-face survey conducted by a coalition of independent non-partisan academics and international organisations. The core project partners include The Centre for Democratic Development (CDD-Ghana), Institute for Empirical Research in Political Economy (IREEP), Institute for Development Studies (IDS), The University of Nairobi and Institute for Justice and Reconciliation in South Africa (IJR). The key Nigerian partner is CLEEN Foundation while other project support units include Michigan State University (MSU) and the Democracy in Africa Research Unit (DARU), Centre for Social Science Research, University of Cape Town. The Nigerian survey is part of the Afrobarometer project which seeks to feel the democratic pulse of several African nations (Bratton 2013). The survey data used here was collected in 2012.

The first step in the analysis was the determination of battleground states. This was achieved by identifying those states where the PDP appeared vulnerable. We calculated four sets of metrics form the 2011 election results. For each political party, we determined: (a) those states where the votes amassed by the party equals two-thirds or more of all eligible voters in the state; (b) those states where the votes amassed by the party equals two-thirds or more of all the votes cast in the state; (c) those states where the votes amassed by a party are greater than half but less than two-thirds of all eligible voters in the state; (d) those states where the votes amassed by a party are greater than half but less than two-thirds of votes cast in the state. 
We evaluated the spatial and temporal changes in the distribution of eligible voters. This was achieved by assessing the voter's registration data published by the Nigerian INEC. The share of voters registered in 2015 was compared with the share of voters registered in 2011 across all states. This analysis also helped to provide an initial glimpse of some aspects of the behaviour of electorates within the battleground states.

We estimated the propensity for voters to exhibit at least five additional electoral traits and drivers of the 2015 election. These include:

a. Voter apathy

b. Swing voting

c. Voting intention as a result of public perception on corruption

d. Voting intention as a result of public perception on insecurity

e. Voting intention as a result of public perception on the state of the economy Propensity measures were calculated using the notation given in Equation 1.

$$
\text { Propensity Index }=\left[\left(n / \sum_{1}^{k} n\right) \div\left(N / \sum_{1}^{k} N\right)\right]
$$

Where,

$n$ is the count of people exhibiting a particular electoral trait (e.g. may not vote in elections) in geodemographic typology $\mathrm{k}$

$N$ is the count of adult population in geodemographic typology k $k$ is the total number of geodemographic typologies 
The model used to calculate LGA level propensities for different electoral traits relates the weighted distribution of survey respondents across geodemographic typologies with LGA level adult populations (aged 20 years and above) used as the base. A propensity index were calculated for each geodemographic typology at the group level of the Nigerian geodemographic classification system. A score of 100 indicates a level of occurrence of an electoral issue equal to the national mean or expected level. An area with a score of 150 would indicate a level 50\% above the national average and a score of 200 twice the expected rate (Harris et al. 2005).

We gauged the propensity for voter apathy by calculating the likelihood that voters would abstain from elections. Crewe et al. (1992) provided a definition for voter apathy. According to them, apathy symbolises a lack of feeling of personal responsibility and indifference for political affairs. A typical apathetic voter does not consider the need to participate in participate in electoral proceedings as a priority (Crewe et al. 1992; INEC and FES 2011). There is no universal measure for apathetic voter. For this study, three variables from the Afrobarometer study were combined to gauge voter apathy. These variables include

a. Those respondents that did not register to vote

b. Those respondents that registered and decided not to vote

c. Those respondents that indicated that they did not have the time to vote.

The second trait that was modelled is the propensity for voters to swing in the direction of any political party. Mayer (2007) defined a swing voter as an individual "who is not solidly committed to one candidate or the other as to make all efforts of persuasion futile” (Mayer, 2007 p. 359). Weghorst and Lindberg (2013) further 
explained the factors that determine the decision-making protocol of African swing voters. Using empirical evidence from Ghana, they challenged the notion that African electorates tend to vote on the basis of ethnic cleavages and clientelistic networks. They discovered that the performance of incumbent politicians is an important driver of how swing voters behave in Africa.

There is no consensus in the literature about how to measure swing voting. Measures that have been used include self-reported ambivalence (Hoffman et al. 2009), lack of party affiliation (Lindbeck and Weibull 1987) and past voting behaviour (Shaw 2008). For this study, lack of party affiliation was used. The Afrobarometer study asked respondents to specify the political party they would support in a presidential election. Those respondents who indicated that they would vote for the candidate and not a specific political party were identified as swing voters.

From the Afrobarometer survey, we also modelled the propensity to vote against the incumbent president on the basis of three main drivers of the 2015 election (corruption, insecurity and the economy). We created a contingency table of those respondents who indicated that they would not vote for Goodluck Jonathan by the three reasons given for their disaffection with the Jonathan administration.

In addition to estimating the propensity indices, we calculated the probabilities of voting against the incumbent president (Goodluck Jonathan) by initially deriving the odds of voting against him. The odds were converted to probabilities in the thirteen battleground states identified. The probabilities simply express the chance of voting 
against Goodluck Jonathan as a ratio of the number of desired outcomes (adults who were not prepared to vote for the ruling party) to the total number of possible outcomes.

\section{Battleground States}

Section 133 (b) of the Nigerian 1999 constitution makes it clear that the winner of any presidential contest needs to win at least two-thirds of all the states in the federation and the Federal Capital Territory (FCT), Abuja (World Intellectual Property Organization 2016). In principle, the winner needs to dominate at least 24 of the 37 administrative territories (36 states and 1 FCT).

[Figure 1 about here]

To delineate the battleground states ahead of the 2015 election, it was instructive to re-visit voting dynamics in 2011. Figure 1 shows the thresholds of majority held by each party in 2011. The map was produced by analysing the share of votes cast for each party in each state and examining the relationship between votes cast and eligible voters. The APC was not in existence during the 2011 election. Therefore, in order to determine the majority thresholds for the APC, we combined the share of votes that accrued to the ACN, CPC and ANPP in that election. The votes cast for APGA were not included. They were considered negligible since only a faction of APGA merged with the other three parties (Thurston 2015). In 2011, the PDP won all states with a shade of red while the APC dominated in states with a shade of blue.

From the analysis, it is evident that Osun State was the epicentre of the APC in the South West geo-political region and that the key targets of the APC were situated within the South West and North Central geo-political regions. 
There are two categories of battleground states. The first group are 8 states where the PDP recorded greater than half but less than two-thirds of votes cast in the corresponding state. These are states where the PDP appeared to be most vulnerable and they include Ogun, Oyo, Ekiti, Kwara, Abuja FCT, Nasarawa, Taraba and Adamawa States.

The second group of battleground states are a selection of 5 states where the PDP two-thirds or more of all the votes cast in the corresponding state. These states are also listed with the most vulnerable first. They include Lagos, Benue, Kogi, Plateau, and Ondo States.

In Figure 2, we show the rates at which registered electorates turned out to vote during the 2011 election. In a two-horse race as was the case in the 2015 election, voter turn-out can be crucial in deciding the direction in which a fiercely contested territory ultimately swings.

[Figure 2 about here]

The analysis reveals that turn-out was particularly low in all the South West states indicating substantial concentration in this region, of electorates who were disaffected with democratic governance and the electoral process during the 2011 election. Turnout was also low in Kwara and Sokoto States. Interestingly, engagement with the electoral process seems to have been greater within key PDP strongholds than in the APC strongholds. In summary, all the 13 battleground states appear to exhibit significant levels of disaffection with the electoral process. 


\section{Multiple Registrations and Space-time Change in Eligible Voters}

In 2011, the Independent National Electoral Commission (INEC) announced that close to 74 million adults registered to vote in the presidential election (Iheduru 2014). However, the true figure was slightly over 70 million people (Ibeanu et al. 2010; Voa 2011). Following the 2011 presidential election, INEC consolidated and optimised the national voters register in order to eliminate multiple registrations (INEC 2011). About 4 million duplicate registrations were detected (Nwafor 2015; Sule 2015).

[Figure 3 about here]

Figure 3 shows the rates at which multiple registrations was detected. The national average rate for multiple registrations was 5.7\%. Rates varied from as low as o.2\% to $14 \%$. Duplicate registration was particularly pervasive in 17 states listed in Table 2.

[Table 2 about here]

Amongst the 17 states fingered for higher than average duplicate registrations in 2011, the PDP dominated in 11 whilst APC (comprising the three surrogate parties) won 6 states. A total of 20 states did not report greater than average rates. The calculation for the APC in 2011 was based on the combination of votes from three surrogate parties - ACN, CPC and ANPP.

Figure 4 compares the share of voters registered in 2015 with those registered in 2011 across all states. The numbers on each side of the pyramid sum up to $100 \%$ for each year. In both years, Lagos and Kano dwarf the other states. Lagos was a keenly contested state during the 2015 election. 
[Figure 4 about here]

Rates of registration and turnout of voters matter because most people perceive democratic processes to be more legitimate when participation is high (Dalton 2008; Lijphart 1997). It is not quite clear what accounted for such a substantial decline in the number of eligible voters by 2015. The significant reduction in numbers suggests that an increase in voter education alone may not be sufficient to reverse the strength of voter apathy amongst Nigerian electorates. Perhaps people may become better engaged when they perceive that electoral malpractices have diminished and they discover that their votes actually 'count' (Birch 2010).

Scholars have argued that voter education ensures that electorates are ready, willing, and able to fully engage in electoral processes (Persson 2013; Hillygus 2005; Tenn 2007). It is presumed that effective education of voters can act as the motivating force for driving an agile body of electorates (INEC and FES 2011). However, just over 68 million eligible voters registered to take part in the 2015 election (Mbachu et al. 2015; Welsh 2015). Compared to the 2011 optimised voters register, there was a shortfall of around 1.5 million adults.

Four states witnessed significant reductions in terms of their share of the universal number of voters. These include Borno (0.9 percentage points), Sokoto (0.7 percentage points), Bauchi (0.6 percentage points) and Niger (0.5 percentage points). Figure 5 paints a picture of the scale of change in the number of eligible voters across states.

[Figure 5 about here] 
The largest reductions in the number of eligible voters were in the northern half of the country. Reductions in Borno State (25\%) is understandable. It is directly linked to the Boko Haram insurgency which was also a hot topic in the 2015 election. Reductions in Sokoto (24\%) may be linked to the consolidation and optimisation of the voter's register conducted by INEC. There was a 14\% duplicate registration rate in Sokoto State during the 2011 presidential election. These registrants were weeded out of the 2015 electoral register by INEC.

It is also noteworthy to mention that eligible voters fell in some battleground states notably Benue State (14\% reduction), Adamawa State (7\% reduction), Plateau State (4\% reduction), Oyo State (3\% reduction) and Abuja FCT (1\% reduction). Battleground states that witnessed significant rises in the number of registered voters include Lagos State (7\% rise) and Ekiti State (6\% rise). Both states are located in the South West and were set to be contested fiercely in the 2015 election.

\section{Abstinence from Elections}

Voter apathy occurs when electorates become nonchalant about democracy and it is often caused by distrust for politicians (INEC and FES 2011). The turnout of voters for presidential elections has recently been diminishing in Nigeria. Nigeria witnessed a long period of autocratic rule under several military juntas. Following the return to democratic governance, just over half (52\%) of registered voters participated in the 1999 presidential election (INEC 2011). Turnout rose to around 69\% in 2003 (Ntuk 2016). However, disaffection increased noticeably amongst registered voters following the 2003 election. In 2007, the turnout of voters dropped to approximately 56\% (IRI 2007). A further reduction was recorded in 2011 when turnout fell to near post-military 
junta era. The turnout for 2011 according to INEC was approximately 54\% (CPPA 2015).

Halfway into former president Jonathan's tenure, abstinence from elections had become more pronounced in some types of localities compared to others. Figure 6 illustrates the levels of disaffection with the political process amongst Nigerian adults. Results are extrapolations of the geodemographic modelling.

[Figure 6 about here]

The propensity indices can be interpreted using the classification in Table 3.

[Table 3 about here]

In affluent urban localities, the predisposition to stay away from elections was nearly treble the national average rate. These LGAs are generally characterised by disproportionate representations of middle-aged populations and a substantial number of pensioner households. Literacy rates are generally very high within these areas with high secondary school completion rates.

It is also interesting is that apathy is high ( $57 \%$ above the national mean) amongst adults in disadvantaged urban vicinities. These LGAs are comprised of the largest national representation of residents employed in public sector roles.

Amongst the battleground states, residents of Lagos State LGAs have very high tendency to abstain from elections. Abuja FCT, Nasarawa and some pockets in Kwara, Oyo, Ogun and Ondo states also display high levels of apathy. 


\section{Distribution of Swing Voters}

A substantial number of Nigerian electorates gauge political parties in terms of their alignment to ethnic or religious issues (Nnabuihe et al. 2014; Adibe 2015). However, some electorates remain undecided until very close to the election. Such electorates are described as floating or undecided voters (Arcuri et al. 2008). In a twohorse race like the 2015 election, undecided voters can be important in determining the how tightly-contested states swing.

The data analysis revealed that approximately 2 in 10 adults were undecided halfway into Goodluck Jonathan's tenure in office. Figure 7 also shows that by the middle of Goodluck Jonathan’s tenure, indecision amongst potential voters was disproportionately higher in the southern half of the country. Interestingly, states in the South East geo-political zone showed greater propensity to swing in any direction. This zone is a traditional stronghold of the former president.

[Figure 7 about here]

Amongst the battleground states, adults in Lagos displayed disproportionately high concentration of undecided voters. This again explains why Lagos State was keenly contested in the 2015 election.

For many of the undecided voters, the battle of making a choice is generally difficult because they are not convinced that the democratic process provides electorates with the real options that would make much difference to their lives (Luntz 2016). They feel that the options often presented to them hardly conform to their views and expectations resulting from their lived experiences. 


\section{The Political Temperature of Battleground States}

Traditionally, politicians use rhetorical strategies of creed and ethnicity to trick voters during elections in Nigeria (Nnabuihe et al. 2015; Adegbami and Uche 2015). Therefore, most elections have been fought on those fault-lines which divide rather than unite the nation. We argue that social problems like poverty and inequality, inadequate health-care, poor education, absence of infrastructure, crime, social disorder and unemployment do not self-select people on the basis of their religion or ethnic affiliation. This explains in part why voting based on religion or ethnicity does not yield the basic dividends of democracy which the average Nigerian craves for.

Numerous public intellectuals and NGOs within and outside Nigeria made relentless effort to better educate the Nigerian voting public prior to the 2015 election (IRI 2015). Public awareness of key issues increased resulting in increased probing of leadership tenets (Jega and Hillier 2012; IRI 2015). In part, this triggered a semblance of an issue-based campaign in 2015.

Corruption, insecurity and the state of the economy were the key drivers of the 2015 presidential debates. So, what did the political temperature of Nigeria look like in battleground states midway into former President Jonathan's tenure? Results from the geodemographic modelling are presented in Figures 8 to 10.

[Figure 8 about here]

[Figure 9 about here]

[Figure 10 about here] 
Agbiboa (2011), Mohammed (2013), Osimen et al. (2013), Ogbewere (2015) and Kieghe (2016) have described the perpetuation of corruption in public service as a major reason for the inability of the Nigerian state to rise out of the shadows and fulfil its potential on the African continent and the global stage. Corruption has also been linked to the Boko Haram insurgency ravaging some states in the North East geopolitical zone (Agbiboa 2013a: Agbiboa 2013b). Whilst many Nigerians at the grass roots are fed-up of the corruption entrapment, they feel powerless about the situation. Indeed, the former Nigerian Finance Minister, Dr Ngozi Okonjo-Iweala admitted in February 2015 that corruption persists in Nigeria because the country lacks institutions, systems and processes to prevent it (Onyedika 2015).

Analysis of the Afrobarometer data revealed that halfway into former President Jonathan's tenure, only $2 \%$ of Nigerian adults believed that the president and his inner caucus was not corrupt. When compared to the overall distribution of adults, adults within a few deprived rural LGAs exhibited the greatest likelihood (more than double the national average rate) to express discontentment with corruption in the presidential circle.

There was also an expression of moderately high levels of negative sentiment towards Goodluck Jonathan on corruption within averagely thriving ethnically mixed LGAs where polygamous marriages are quite prevalent. Some LGAs with urban characteristics also subsumed higher than average representations of electorates who were discontented with corruption in central government. The map in Figure 8 suggests that there was generally strong discontentment on corruption in LGAs within Lagos State and Abuja FCT. 
The Boko Haram insurgency in the North East receives the greatest attention from commentators and policy makers. By the middle of Goodluck Jonathan’s tenure, approximately 6 in 10 adults reached the conclusion that he was quite weak on national security. Across the battleground states, LGAs in Lagos, Abuja FCT, Ondo and Nasarawa States harboured the largest concentration of adults discontented with the security situation. Figure 9 also shows pockets of significant discontentment in Adamawa and Plateau States where communal conflicts have been widespread.

Under former President Jonathan’s watch, Nigeria re-calibrated (rebased) its gross domestic product (GDP) to include some industry sectors that were previously unaccounted for (Guardian 2014). The process of rebasing of Nigeria’s economy propelled it to the position of largest economy in Africa above South Africa.

Official statistics on poverty, income inequality and unemployment in Nigeria can often make bleak reading especially when juxtaposed with countries that are presumably less wealthy. Even though Nigeria's economy grew at an average of around 7\% since the beginning of the current millennium (Masseti 2014), this did not translate into improved welfare conditions and in part contributed to the new wave of social conflicts witnessed in various parts of the country (Anderson and Reynolds 2016). Economic growth in Nigeria has been far less poverty-reducing than in many other comparable developing nations that belong to the MINT (Mexico, Indonesia, Nigeria and Turkey) economic cluster for instance (Durotoye 2014). Under the Jonathan administration, too many Nigerians felt there was a mismatch between economic growth and reductions in inequality (Hassan 2015). 
Around 6 in 10 adults were already discontented with the way the economy was being managed by the time Goodluck Jonathan reached the middle of his tenure. Adults in deprived rural LGAs were most unlikely to be happy with the way the economy was being run. Figure 10 shows high levels of dissatisfaction in urban centres. Lagos and Abuja again harbour scores of adults who were highly likely to be unhappy with the fact that economic growth was not translating into improved living standards.

The patterns of discontentment modelled for geodemographic segments at LGA scale in Figures 8 to 10 suggest two splits for the battleground states. Those battleground states on the left generally appear to be more discontented with the Jonathan administration than those on the right side. One would expect this sort of intelligence to inform both the strategic and operational campaign agendas of the political parties. Former President Jonathan faced the monumental challenge of preparing answers for questions about his performance especially in the areas of corruption, insecurity and the economy (Birrell 2015; Adibe 2015).

\section{The Probability of Voting against the Incumbent President}

In this section, we discuss the probability of voting against Goodluck Jonathan during the 2015 election in the 13 battleground states. Probabilities were computed for these states and compared with the tipping point. The tipping point is the point at which the probabilities of voting for or against the former president are equally likely (i.e. a probability of 50\%). Results are summarised in Figure 11.

[Figure 11 about here] 
Figure 11 gives an indication of how adults who were disgruntled about corruption were prepared to vote across the battleground states. The analysis revealed that the probability of voting the former president out of office had reached or risen above tipping point in 6 battleground states namely: Ogun (72\%), Lagos (70\%), Taraba (53\%), Ondo (52\%), Oyo (51\%) and Adamawa (50\%) States. Two other states - Ekiti (46\%) and Kwara (42\%) were also close to the tipping point.

Results presented in Figure 11 also shows the voting probabilities for those adults who indicated that they were displeased with the former president's handling of public safety and security. Amongst this group, the probability of voting Jonathan out of office had reached or risen above tipping point in 7 battleground states. The states include Ogun (71\%), Kwara (71\%), Lagos (69\%), Adamawa (62\%), Oyo (60\%), Taraba (57\%) and Nasarawa States (50\%). Ondo and Ekiti State were also already heading closer to the tipping point with $45 \%$ and $41 \%$ probabilities respectively.

The bar chart shown in Figure 11 also provides an indication of how adults who were disaffected with the management of the economy were prepared to vote. The probability to vote against the Goodluck Jonathan had reached or risen above tipping point in 6 of the battleground states. These include Ogun (74\%), Lagos (69\%), Taraba (58\%), Oyo (57\%), Ondo (52\%) and Adamawa (51\%) States. Ekiti State was also very close to the tipping point with $48 \%$ probability while there was a $41 \%$ chance of voting against the former president in Kwara State.

Abuja particularly presents an interesting contrast. Even though public perception on these core issues was generally negative in most LGAs in Abuja as shown 
in Figures 8 to 10, it still had not translated into a high probability of voting against the former president by the middle of his tenure. Amongst the battleground states, only 4 (Ekiti State, Plateau State, Kogi State, Abuja FCT) consistently recorded low probabilities of voting against the president mid-way into his presidency.

\section{How Well Did the Empirical Forecast Perform?}

The empirical forecast discussed in this paper revealed that by the middle of Goodluck Jonathan's tenure, his public approval ratings had plummeted across the entire country. The average probability of voting against him across all the states and FCT had already risen above the tipping point of $50 \%$. There was a $53 \%$ chance that Nigerian adults who perceive the presidency as institutionally corrupt would vote against the former president. For those adults unhappy with the handling of security matters, their probability of voting against Goodluck Jonathan was 56\% whilst those who disclosed that they were unhappy with the handling of the economy recorded a $55 \%$ chance of voting against the president.

Results from our forecast are consistent with the final outcome of the 2015 presidential election. The election results were close. Muhammadu Buhari of the APC amassed 53.96\% of the total votes whilst Goodluck Jonathan of the PDP recorded $44.96 \%$.

The Nigerian INEC has not released the breakdown of detailed results at the LGA scale so it impossible to evaluate our LGA forecasts against the actual outcome. However, state level results have been published therefore we compare our state level forecasts within the 13 battleground states the actual outcome. 


\section{[Table 4 about here]}

Table 4 compares results from the probability analysis with the actual shares of votes recorded during the presidential election. The probability forecasts for nine battleground states (Abuja FCT, Adamawa, Ekiti, Lagos, Nasarawa, Ogun, Ondo, Oyo and Plateau) were consistent with the final outcome of the election. The results in four states were inconsistent with our forecasts. This yields a 69\% success rate. Given that the data used for the analysis was collected mid-way into the administration of Goodluck Jonathan (two years before the presidential election), it is fair to say that on balance the empirical forecast analysis performs creditably well.

\section{Conclusion}

This article summarised the techniques used to determine the main administrative territories that were expected to decide the winner of Nigeria's 2015 presidential election. The authors discovered that around 35\% of all eligible voters were responsible for the determination of the outcome of the election. These $35 \%$ were situated in 13 battleground states. Essentially, the PDP needed to hold on to their majority in these states whilst the APC needed to overturn the dominance. The article also used a robust spatial data analytical approach to evaluate the strength of public anger against former President Goodluck Jonathan within these 13 battleground states. The authors discover that mid-way into his tenure, Goodluck Jonathan’s public approval ratings had plummeted significantly in many LGAs within these battleground states and he was already on the verge of losing majority in at least 10 of the states. He eventually lost 8 of the 13 states which resulted in victory for Muhammadu Buhari. 


\section{References}

Adegbami, A. and Uche, C. 2015. "Ethnicity and Ethnic Politics: An Impediment to Political Development in Nigeria.” Public Administration Research 4: 59-67.

Adibe, J. 2015. “The 2015 Presidential Elections in Nigeria: The Issues and Challenges.” In Foresight Africa: Top Priorities for the Continent in 2015, edited by A. Sy, 3-9. Washington, D.C.: Brookings Institution.

Agbiboa, D. 2013a. "The Ongoing Campaign of Terror in Nigeria: Boko Haram versus the State.” International Journal of Security and Development 2: 1-18.

Agiboa, D. 2013b. "Why Boko Haram Exists: The Relative Deprivation Perspective." African Conflict and Peacebuilding Review 3: 144-157.

Anderson, L. and Reynolds, T. 2015. "Economic Growth and Poverty in Nigeria." Washington: Evans School of Public Policy and Governance.

Arcuri, L., Castelli, L., Galdi, S., Zogmaister, C. and Amadori, A. 2008. "Predicting the Vote: Implicit Attitudes as Predictors of the Future Behaviour of Decided and Undecided Voters.” Political Psychology 29: 369-38.

Bartlett, J. et al. 2015. "Social Media for Election Communication and Monitoring in Nigeria.” London: Demos.

BBC 2013. "Nigeria Opposition Merges to Form APC and Challenge PDP.” Available at: http://www.bbc.co.uk/news/world-africa-21370540 [Accessed 23 August 2016].

Birch, S. 2010. "Perceptions of Electoral Fairness and Voter Turnout.” Comparative Political Studies, 43: 1601-1622.

Birrell, I. 2015. "Goodluck Jonathan: Nigeria's Head of State Has Bumbled in Response to Boko Haram. With Elections Close, His Demise May Be Imminent.” Available at: http://www.independent.co.uk/news/people/profiles/goodluck-jonathan-nigerias-headof-state-has-bumbled-in-response-to-boko-haram-with-elections-close-9984317.html [Accessed 6 December 2016].

Bratton, M. (ed.) 2013. “Voting and Democratic Citizenship in Africa.” Boulder, CO: Lynne Rienner Publishers.

Carty, K. and Eagles, M. 1999. "Do Local Campaigns Matter? Campaign Spending, the Local Canvass and Party Support in Canada.” Electoral Studies 18: 69-87.

CPPA 2015. “2015 Presidential Election Outcome: Analyses \& Implications.” Abuja: Centre for Public Policy Alternatives.

Crewe I., Fox. T. and Alt J. 1992. "Non-voting in British General Elections, 1966October 1974.” In D. Denver and G. Hands Issues and Controversies in British Electoral Behaviour. Hemel Hempstead: Harvester Wheatsheaf. 
Dalton, R. J. 2008. “Citizenship Norms and the Expansion of Political Participation.” Political Studies 56: 76-98.

Durotoye, A. 2015. "The MINT Countries as Emerging Economic Power Bloc: Prospects and Challenges.” Developing Country Studies 4: 99-106.

Guardian 2014. “Nigeria Becomes Africa's Largest economy - Get the Data.” Available at: https://www.theguardian.com/global-evelopment/datablog/2014/apr/07/nigeriabecomes-africa-largest-economy-get-data. [Accessed 1 December 2016].

Harris, R., Sleight, P. and Webber, R. 2005. “Geodemographics, GIS and Neighbourhood Targeting.” London: Wiley.

Hassan, O.M. 2015. "The Impact of the Growth Rate of the Gross Domestic Product (GDP) on Poverty Reduction in Nigeria.” International Journal of Business Administration 6: 90-100.

Hillygus, D.S. 2005. “The Missing Link: Exploring the Relationship Between Higher Education and Political Engagement.” Political Behaviour 27: 25-47.

Hoffman, B., Gibson, C., Ferree, K.E. and Long, J.D. 2009. "Explaining the African Vote.” Annual Meeting of the American Political Science Association. Available at: https://ssrn.com/abstract=1450123 [Accessed 3 February 2018].

Ibeanu, O., Stevens, M., Tayo, S. and Banjoka, L. 2010. “Nigeria: Planning and Prospects for the 2011 Elections.” London: Chatham House.

Ibekwe, N. 2015. “How We Defeated PDP - APC’s Election Planning and Monitoring Chief.” Available at: http://www.premiumtimesng.com/news/top-news/183136interview-how-we-defeated-pdp-apcs-election-planning-and-monitoring-chief.html [Accessed 7 December 2016].

Iheduru, O. 2014. “Nigeria.” In Comparative Politics: Interests, Identities, and Institutions in a Changing Global Order, edited by J. Kopstein, M. Lichbach and S. Hanson, 507-568. Cambridge: Cambridge University Press.

INEC 2011. “Report on the 2011 Elections.” Abuja: Independent National Electoral Commission.

INEC and FES 2011. "Voter Apathy and the 2011 Elections in Nigeria.” Abuja: Independent National Electoral Commission.

IRI 2007. "Federal Republic of Nigeria State and National Elections April 14 and 21, 2007: Election Observation Mission Final Report.” Washington, DC.: International Republican Institute.

IRI 2015. “2015 Nigeria Election Observation Report.” Washington, DC.: International Republican Institute. 
Jega, A. and Hillier, M. 2012. “Improving Elections in Nigeria: Lessons from 2011 and Looking to 2015.” London: Chatham House.

Kieghe, D. 2016. “National Ambition Reconstructing Nigeria.” London: New Generation Publishing.

Lijphart, A. 1997. “Unequal Participation: Democracy's Unresolved Dilemma.” The American Political Science Review 91: 1-14.

Lindbeck, A. and Weibull, J.W. 1987. "Balanced-Budget Redistribution as the Outcome of Political Competition.” Public Choice 52: 273-297.

Lunn, J. and Harari, D. 2014. "Nigeria 2015: Analysis of Election Issues and Future Prospects.” London: House of Commons Library.

Luntz, F. 2016. “Frank Luntz: The Myth of the Undecided Voter.” Available at: http://time.com/4424053/frank-luntz-the-myth-of-the-undecided-voter/ [Accessed 8 December 2016].

Masseti, O. 2014. “Nigeria: The No. 1 African Economy.” Frankfurt: Deutsche Bank.

Mayer, William G. 2007. “The Swing Voter in American Politics.” Washington, DC: Brookings Institution Press.

Mbachu, D., Ibukun, Y. and Wallace, P. 2015. "Nigeria Election Results Flow in as Opposition Cries Foul.” Available at: https://www.bloomberg.com/news/articles/201503-28/nigeria-extends-vote-to-second-day-after-polling-station-delays. [Accessed 5 December 2016].

Mohammed, U. 2013. "Corruption in Nigeria: A Challenge to Sustainable Development in the Fourth Republic.” European Scientific Journal 9: 118-137.

Nnabuihe, N.S., Aghemalo, A. and Okebugwu, N.E. 2014. "Ethnicity and Electoral Behaviour in Nigeria.” European Scientific Journal 2: 159-178.

Ntuk, U.G. 2016. "Political Architecture, Electoral Dynamics and Public Delivery of Nigeria's Fourth Republic: An Assessment.” Public Policy and Administration Research 6: 76-83.

Nwafor, C. 2015. "Publication of the Register of Voters for the 2015 General Elections.” Available at: http://www.inecnigeria.org/wpcontent/uploads/2015/01/National-Publication-of-Register-of-Voters.pdf. [Accessed 7 August 2016].

Ogbewere, I.B. 2015. "Anatomy of Corruption in the Nigerian Public Sector: Theoretical Perspectives and some Empirical Explanations.” SAGE Open 5: 1-16.

Ojo, A., Vickers, D., Ballas, D. 2012. “The Segmentation of Local Government Areas: Creating a New Geography of Nigeria.” Applied Spatial Analysis and Policy 5: 25-49. 
Ojo, A., Vickers, D., Ballas, D. 2013. “Creating a Small Scale Area Classification for Understanding the Economic, Social and Housing Characteristics of Small

Geographical Areas in the Philippines.” Regional Science Policy and Practice 5: 1-24.

Onyedika, N. 2015. “Why Corruption Persists in Nigeria, by Okonjo-Iweala.” Available at: http://guardian.ng/news/nigeria/why-corruption-persists-in-nigeria-by-okonjoiweala/. [Accessed 2 December 2016].

Osimen, U.G., Adenegan, S.T. and Balogun, A. 2013. “An Assessment of Corruption in the Public Sector in Nigeria: A Study of Akure South Local Government Area, Ondo State.” Canadian Social Science, 9: 87-97.

Persson, M. 2013. "Is the Effect of Education on Voter Turnout Absolute or Relative? A Multi-Level Analysis of 37 Countries.” Journal of Elections, Public Opinion and Parties, 23: 111-133.

Premium Times 2013. "APC Starts in Crisis as APGA Faction Dissociates Self from Merger.” Available at: http://www.premiumtimesng.com/news/119280-apc-starts-incrisis-as-apga-faction-dissociates-self-from-merger.html [Accessed 30 November 2016].

Said-Moorhouse, L. 2015. "Win it Like Buhari: 5 Startup Lessons to Take Away from Nigerian Elections.” Available at: http://edition.cnn.com/2015/04/09/africa/startuplessons-nigerian-election-buhari-campaign/. [Accessed 30 November 2016].

Shaw, D. 2008. “Swing Voting and U.S. Presidential Elections.” In The Swing Voter in American Politics, edited by W.G. Mayer., 75-101. Washington, DC: Brookings Institution Press.

Sule, I. K. 2015. “INEC: Over 4m Multiple Registrations Eliminated from Voter’s Register.” Available at: http://www.dailytrust.com.ng/daily/news/44279-inec-over-4mmultiple-registrations-eliminated-from-voter-s-register. [Accessed 4 December 2016].

Tenn, S. 2007. “The Effect of Education on Voter Turnout.” Political Analysis 15: 446464.

Tobler, W. 1970. "A Computer Movie Simulating Urban Growth in the Detroit Region.” Economic Geography 46: 234-240.

Thurston, A. 2015. “Background to Nigeria's 2015 Elections.” Washington: Centre for Strategic and International Studies.

Uduma, D. and Emerole, O. 2015. "The Effect of Electoral Malpractices on the Sustenance of Democracy in Nigeria.” International Journal of Advanced Legal Studies and Governance, 5: 71-78.

VOA 2011. "Nigeria's Electoral Commission Says 70 Million Voters Registered for National Elections in April.” Available at: http://www.voanews.com/a/nigeriaselectoral-commission-says-70-million-voters-registered-for-national-elections-in-april116670274/157498.html. [Accessed 20 September 2016]. 
Vickers, D.W. and Rees, P.H. 2006. "Introducing the National Classification of Census Output Areas.” Population Trends 125: 15-29.

Weghorst, K.R. and Lindberg, S.I. 2013. "What Drives the Swing Voter in Africa?” American Journal of Political Science, 57: 717-734.

Welsh, T. 2015. “Nigeria Holds Elections Amid Threats of Violence.” Available at: http://www.usnews.com/news/articles/2015/03/28/nigeria-holds-elections-amid-threatsof-violence-between-factions-boko-haram. [Accessed 6 December 2016].

World Intellectual Property Organization 2016. "Nigeria: Constitution of the Federal Republic of Nigeria 1999.” Available at:

http://www.wipo.int/wipolex/en/text.jsp?file_id=179202. [Accessed 22 August 2016].

Table 1: Hierarchical Structure of the Nigerian Geodemographic System

\begin{tabular}{|c|c|c|}
\hline Supergroups & Groups & Subgroups \\
\hline \multirow[t]{4}{*}{1 - Green Towns } & 1.1 - Conventional Green Towns & $1.1 .1|1.1 .2| 1.1 .3$ \\
\hline & 1.2 - Underprivileged Green Towns & $1.2 .1 \mid 1.2 .2$ \\
\hline & 1.3 - Flourishing Green Towns & \begin{tabular}{l|l|l|}
$1.3 .1 \mid 1.3 .2$ & 1.3 .3 \\
\end{tabular} \\
\hline & 1.4 - Struggling Green Towns & \begin{tabular}{l|l|l|l|}
$1.4 .1 \mid 1.4 .2$ & 1.4 .3 \\
\end{tabular} \\
\hline \multirow[t]{3}{*}{2 - Emerging Localities } & 2.1 - Moderately Emerging Localities & \begin{tabular}{l|l|l|}
2.1 .1 & 2.1 .2 & 2.1 .3 \\
\end{tabular} \\
\hline & 2.2 - Comfortable Emerging Localities & \begin{tabular}{l|l|l|l|}
2.2 .1 & 2.2 .2 & 2.2 .3 \\
\end{tabular} \\
\hline & 2.3 - Transient Emerging Localities & \begin{tabular}{l|l|l|l}
2.3 .1 & 2.3 .2 & 2.3 .3 \\
\end{tabular} \\
\hline \multirow[t]{4}{*}{3 - Intermediate Territories } & 3.1 - Constrained Intermediate Territories & $3.1 .1 \mid 3.1 .2$ \\
\hline & 3.2 - Well-to-do Intermediate Territories & \begin{tabular}{ll|l|l|}
3.2 .1 & 3.2 .2 & 3.2 .3 \\
\end{tabular} \\
\hline & 3.3 - Deprived Intermediate Territories & $3.3 .1 \mid 3.3 .2$ \\
\hline & 3.4 - Customary Intermediate Territories & $3.4 .1 \mid 3.4 .2$ \\
\hline \multirow[t]{4}{*}{4 - Diluted Societies } & 4.1 - Thriving Diluted Societies & \begin{tabular}{|l|l|}
4.1 .1 & 4.1 .2 \\
\end{tabular} \\
\hline & 4.2 - Labouring Diluted Societies & \begin{tabular}{ll|l|l|}
4.2 .1 & 4.2 .2 & 4.2 .3 \\
\end{tabular} \\
\hline & 4.3 - Deprived Diluted Societies & 4.3.1| 4.3.2 \\
\hline & 4.4 - Modest Diluted Societies & \begin{tabular}{l|l|l|}
4.4 .1 & 4.4 .2 & 4.4 .3 \\
\end{tabular} \\
\hline \multirow[t]{3}{*}{5 - Country Dwellings } & 5.1 - Toiling Country Dwellings & $5.1 .1 \mid 5.1 .2$ \\
\hline & 5.2 - Deprived Country Dwellings & $5.2 .1 \mid 5.2 .2$ \\
\hline & 5.3 - Middle-class Country Dwellings & \begin{tabular}{l|l|l|}
5.3 .1 & 5.3 .2 & 5.3 .3 \\
\end{tabular} \\
\hline \multirow[t]{5}{*}{6 - Urban Nodes } & 6.1 - Prosperous Urban Nodes & $6.1 .1 \mid 6.1 .2$ \\
\hline & 6.2 - Disadvantaged Urban Nodes & $6.2 .1 \mid 6.2 .2$ \\
\hline & 6.3 - Average Urban Nodes & $6.3 .1 \mid 6.3 .2$ \\
\hline & 6.4 - Affluent Urban Nodes & $\begin{array}{l}6.4 .1 \mid 6.4 .2 \\
\end{array}$ \\
\hline & 6.5 - Striving Urban Nodes & $6.5 .1 \mid 6.5 .2$ \\
\hline
\end{tabular}


Table 2: States with Pervasive Multiple Voters Registration in 2011

\begin{tabular}{|l|l|}
\hline \multicolumn{1}{|c|}{ States } & Multiple Registration Rate (\%) \\
\hline Sokoto State & 14.1 \\
\hline Yobe State & 13.1 \\
\hline Zamfara State & 11.9 \\
\hline Ondo State & 10 \\
\hline Cross River State & 9.3 \\
\hline Lagos State & 9.3 \\
\hline Abia State & 9.1 \\
\hline Plateau State & 9.1 \\
\hline Oyo State & 8.8 \\
\hline Adamawa State & 8.6 \\
\hline Gombe State & 8.1 \\
\hline Bayelsa State & 7.8 \\
\hline Jigawa State & 7.2 \\
\hline Imo State & 6.6 \\
\hline Nasarawa State & 6.4 \\
\hline Ekiti State & 6.0 \\
\hline Kano State & 5.8 \\
\hline
\end{tabular}

Table 3: Key to Interpreting Propensity Indices

\begin{tabular}{|l|l|}
\hline \multicolumn{1}{|c|}{ Propensity } & Range of Propensity Index Scores \\
\hline Very High & 200 and above \\
\hline High & 151 to 199 \\
\hline Moderately High & 121 to 150 \\
\hline Above Average & 101 to 120 \\
\hline National Average & 100 \\
\hline Below Average & 71 to 99 \\
\hline Moderately Low & 51 to 70 \\
\hline Low & 21 to 50 \\
\hline Very Low & 20 and below \\
\hline
\end{tabular}

Table 4: Probability Forecasts vs. Actual Outcome of Election

\begin{tabular}{|c|c|c|c|c|c|c|}
\hline \multirow{2}{*}{$\begin{array}{l}\text { Battleground } \\
\text { States }\end{array}$} & \multicolumn{3}{|c|}{$\begin{array}{c}\text { Forecasted Probability of Voting Against } \\
\text { President Jonathan (\%) }\end{array}$} & \multicolumn{3}{|c|}{$\begin{array}{c}\text { Actual } \\
\text { Outcome: } \\
\text { Share of Total } \\
\text { Votes }(\%) \\
\end{array}$} \\
\hline & 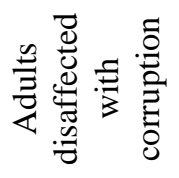 & 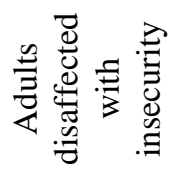 & 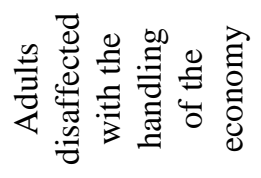 & : & 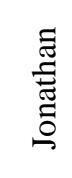 & 苞 \\
\hline Abuja & 24 & 22 & 24 & 48 & 51 & 1 \\
\hline Adamawa & 50 & 62 & 51 & 59 & 40 & 1 \\
\hline Benue & 37 & 41 & 36 & 55 & 44 & 1 \\
\hline Ekiti & 46 & 41 & 48 & 40 & 59 & 1 \\
\hline Kogi & 18 & 12 & 18 & 63 & 36 & 2 \\
\hline Kwara & 42 & 71 & 41 & 69 & 30 & 1 \\
\hline Lagos & 70 & 69 & 69 & 55 & 44 & 1 \\
\hline Nasarawa & 38 & 50 & 29 & 46 & 53 & 1 \\
\hline Ogun & 72 & 71 & 74 & 58 & 39 & 3 \\
\hline Ondo & 52 & 45 & 52 & 53 & 45 & 2 \\
\hline Оуо & 51 & 60 & 57 & 60 & 34 & 6 \\
\hline Plateau & 11 & 14 & 20 & 44 & 56 & 0 \\
\hline Taraba & 53 & 57 & 58 & 45 & 54 & 1 \\
\hline
\end{tabular}




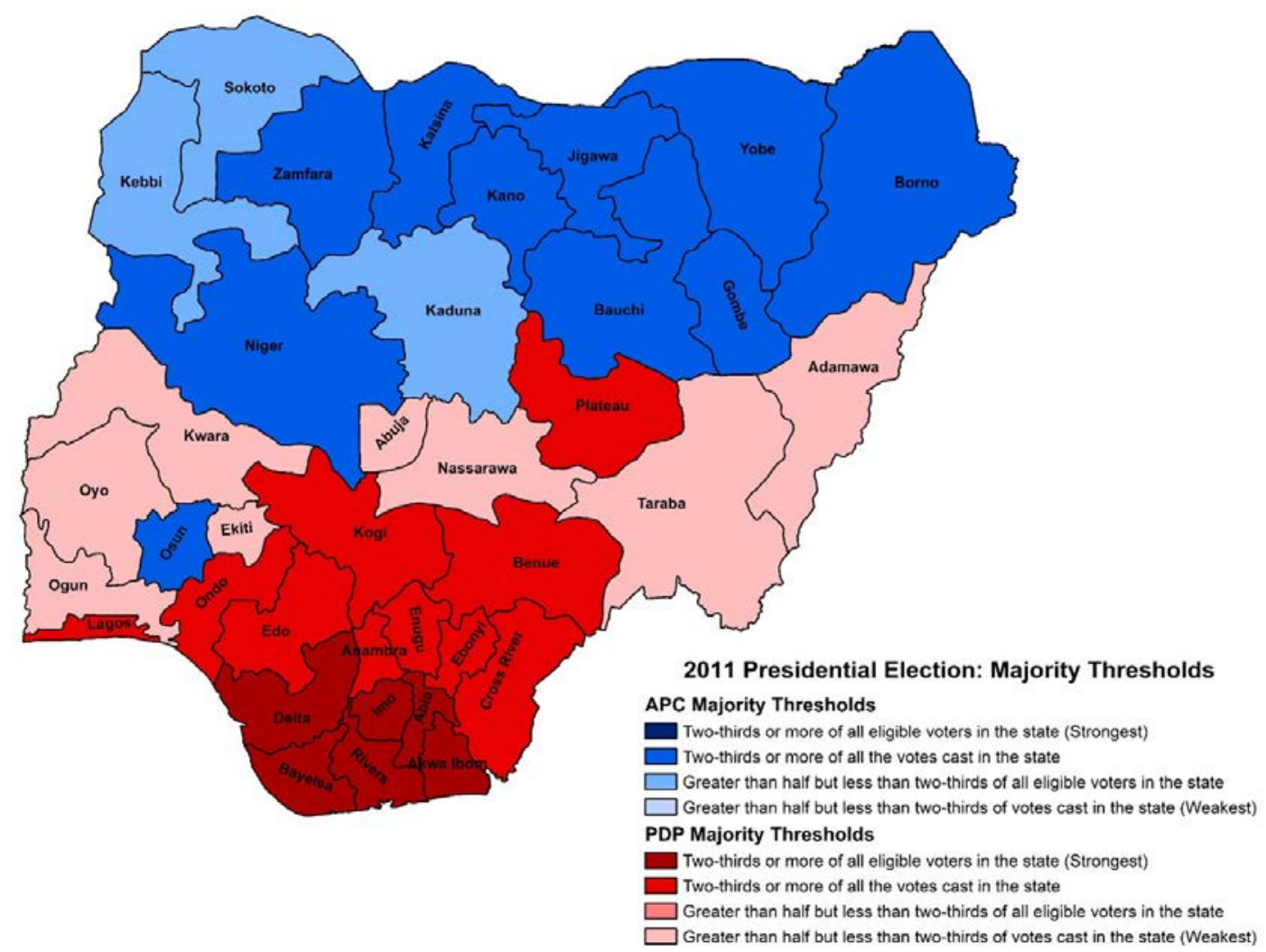


Figure 2

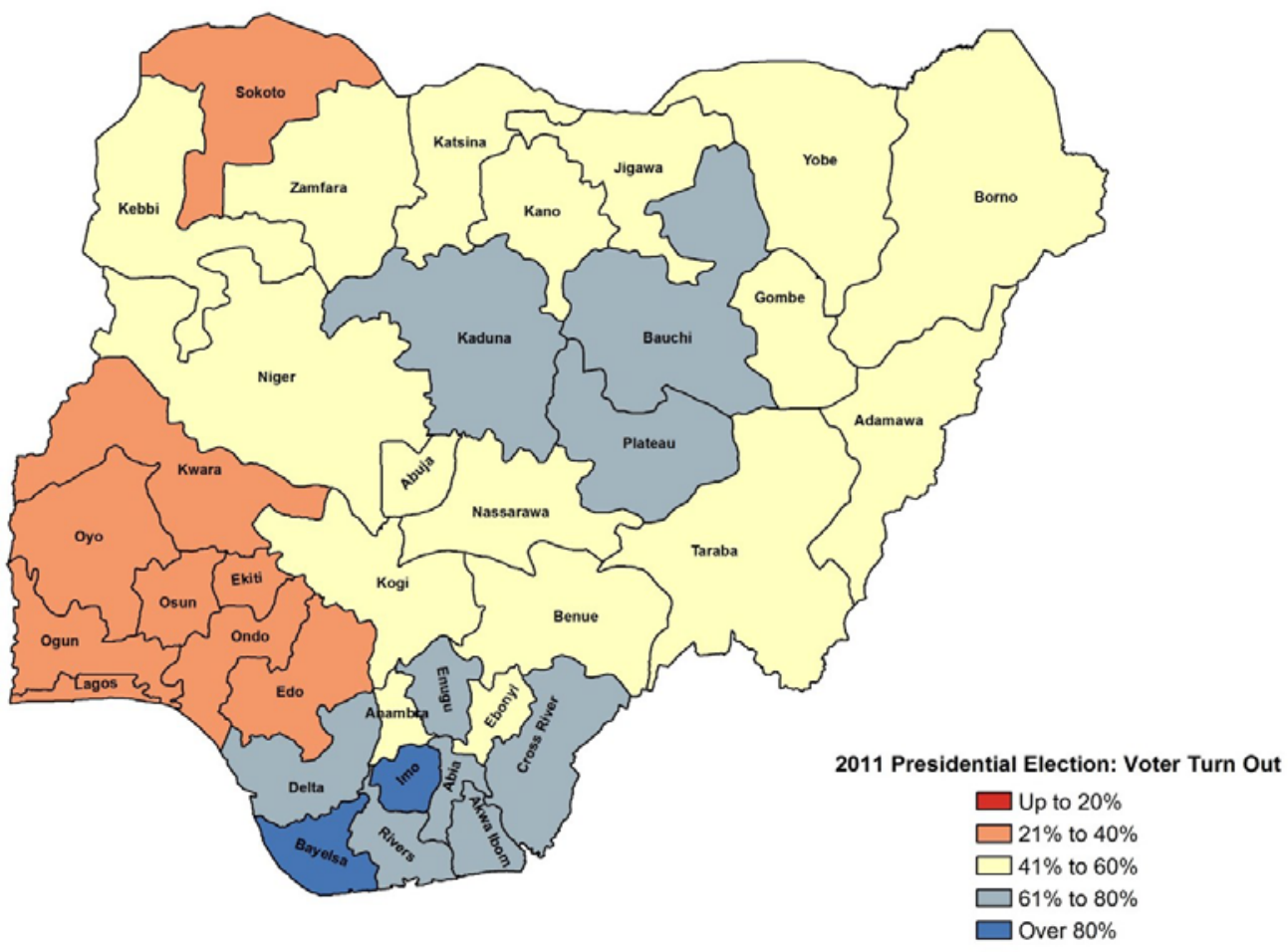


Figure 3

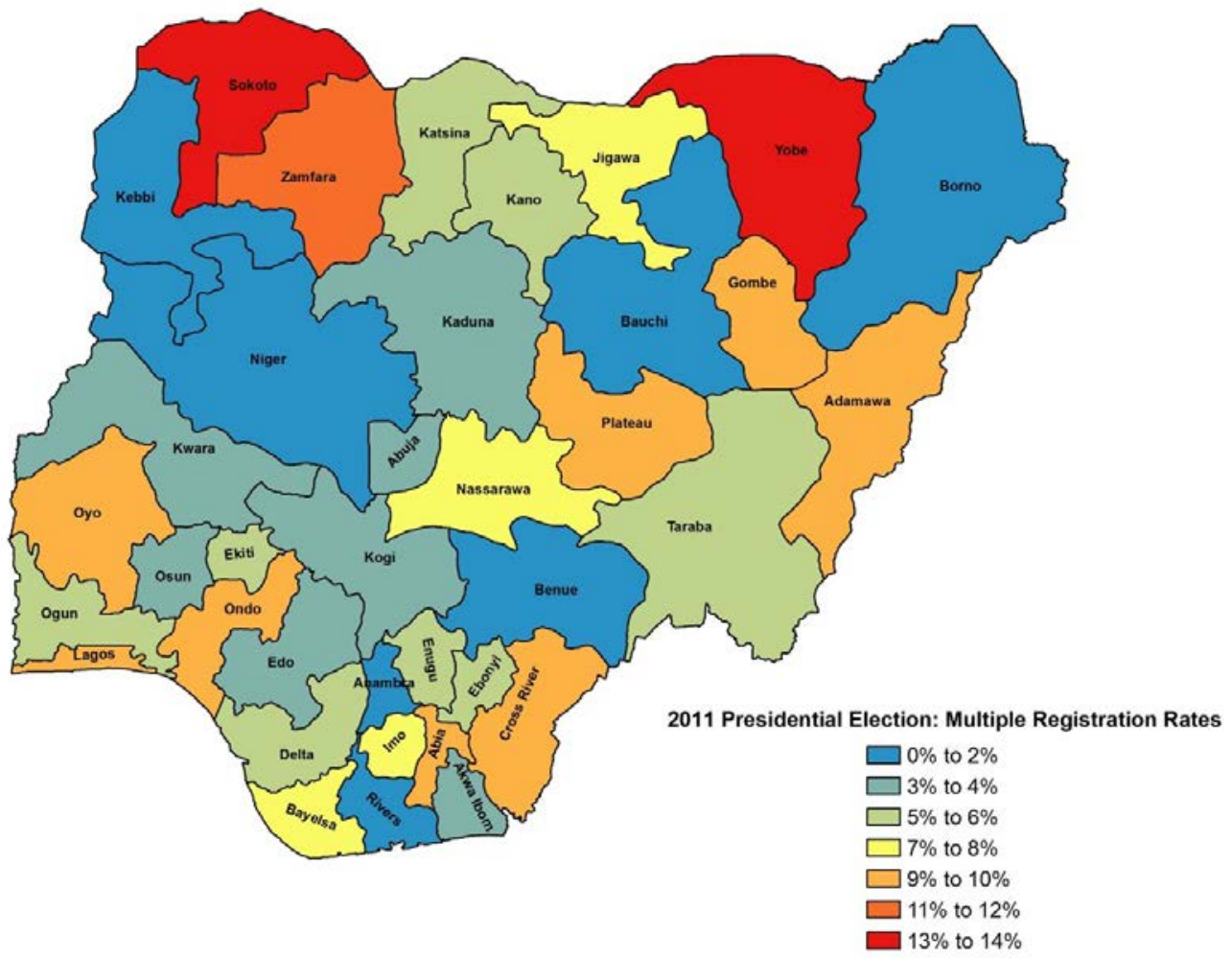

Figure 4

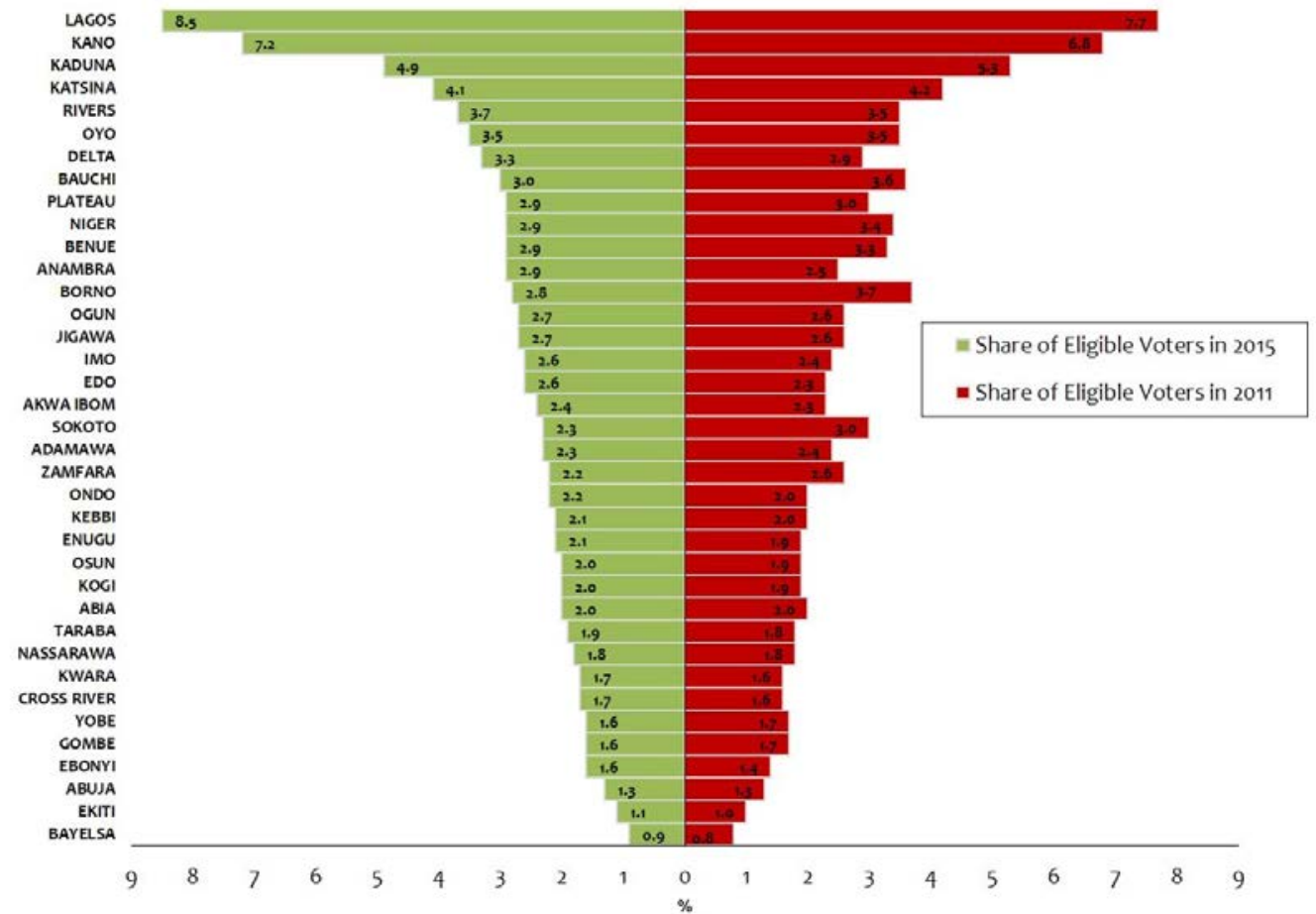


Figure 5

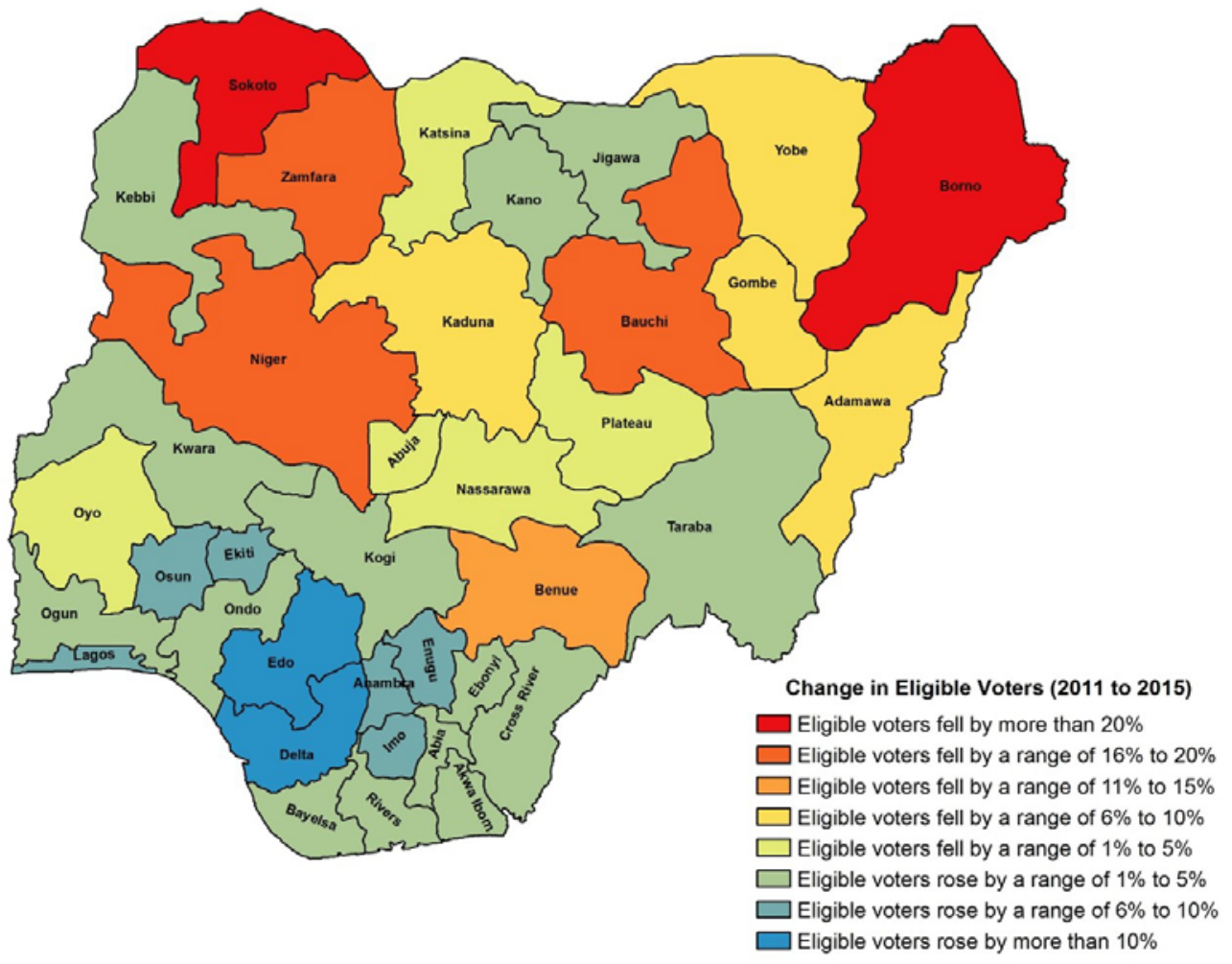

Figure 6

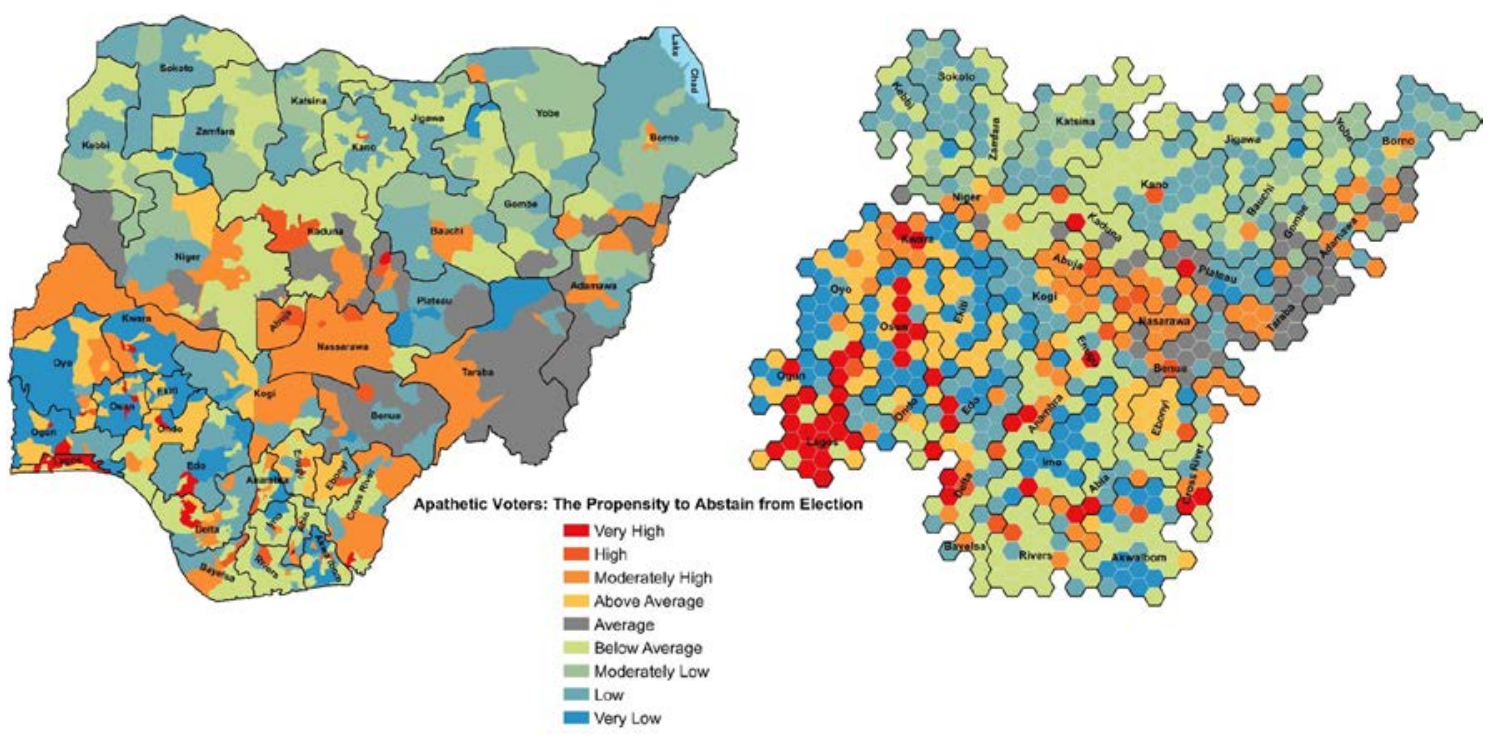


Figure 7

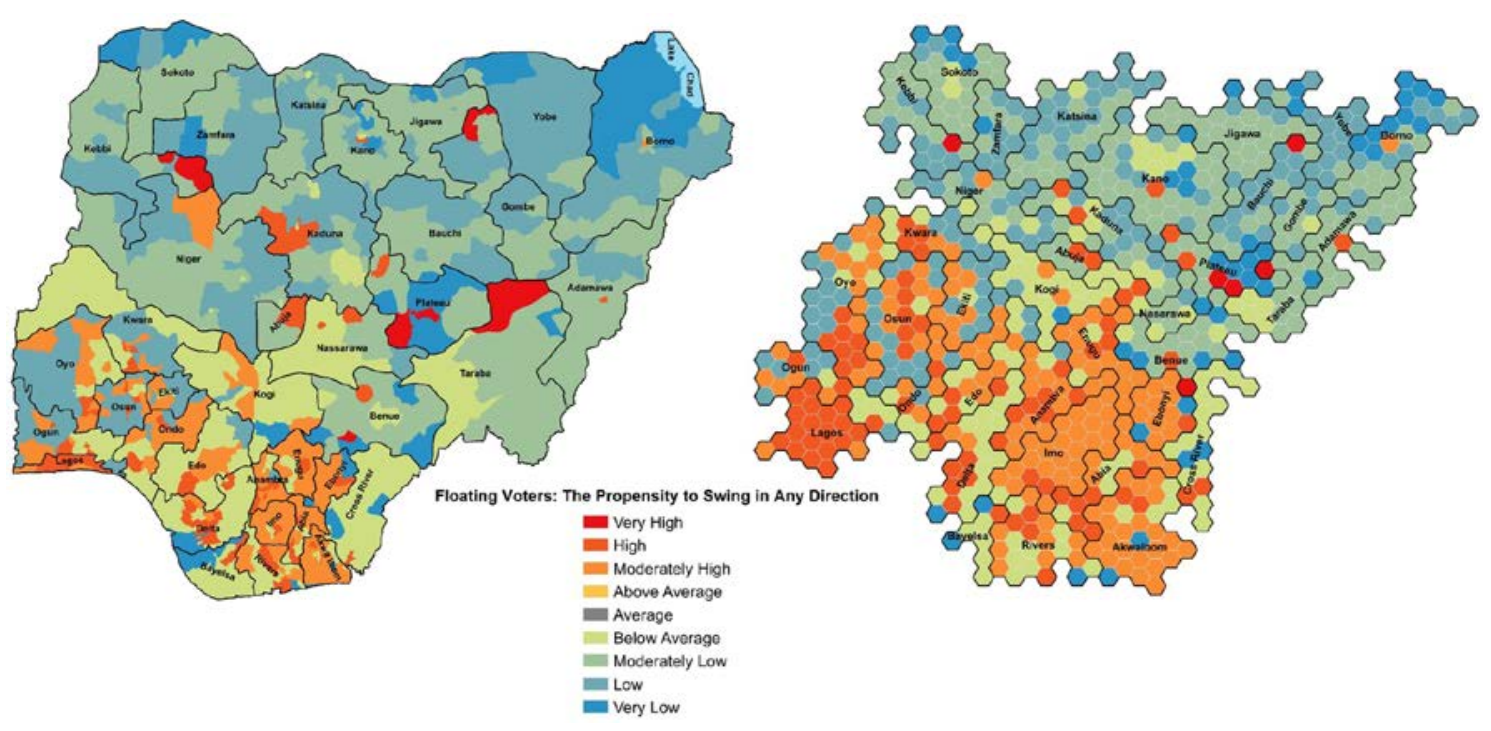

Figure 8

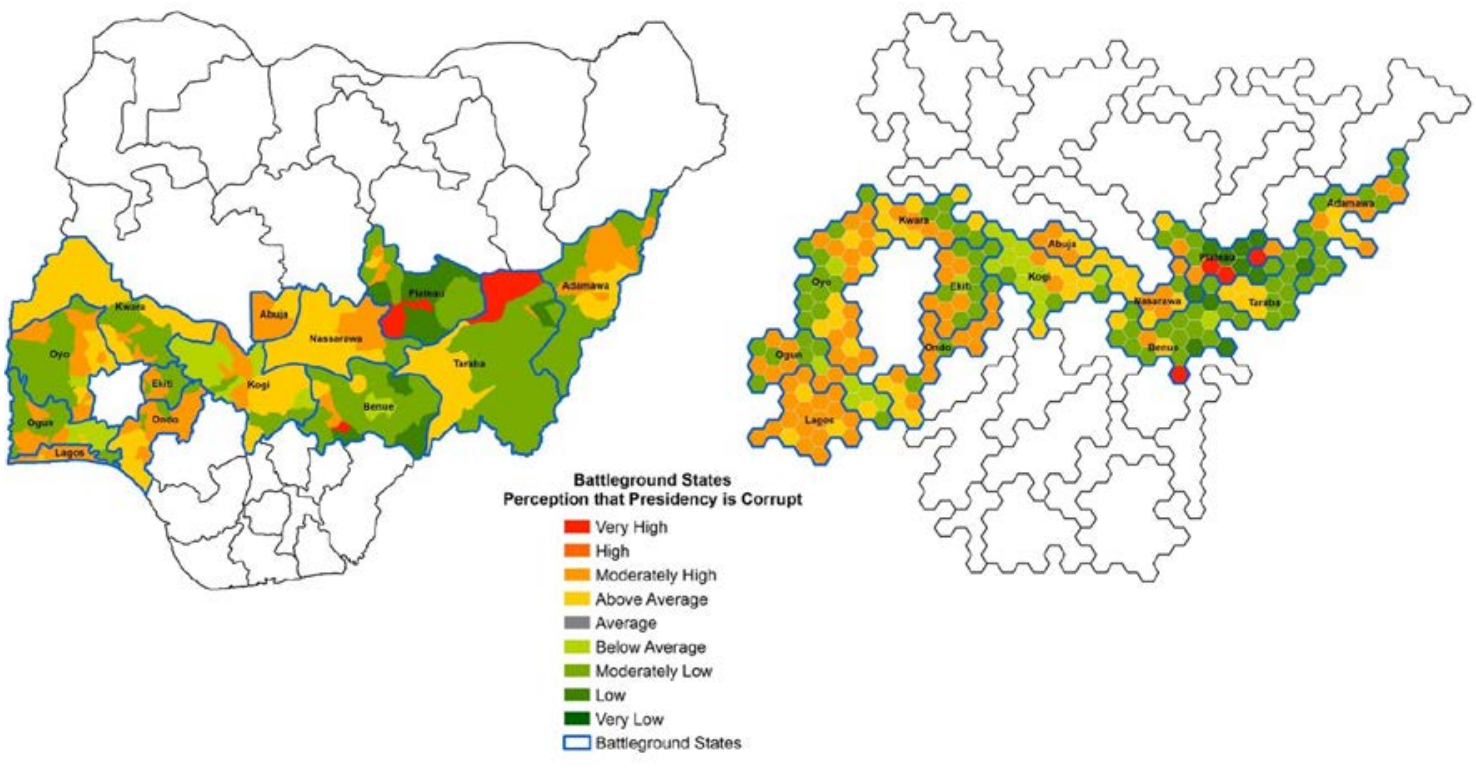


Figure 9

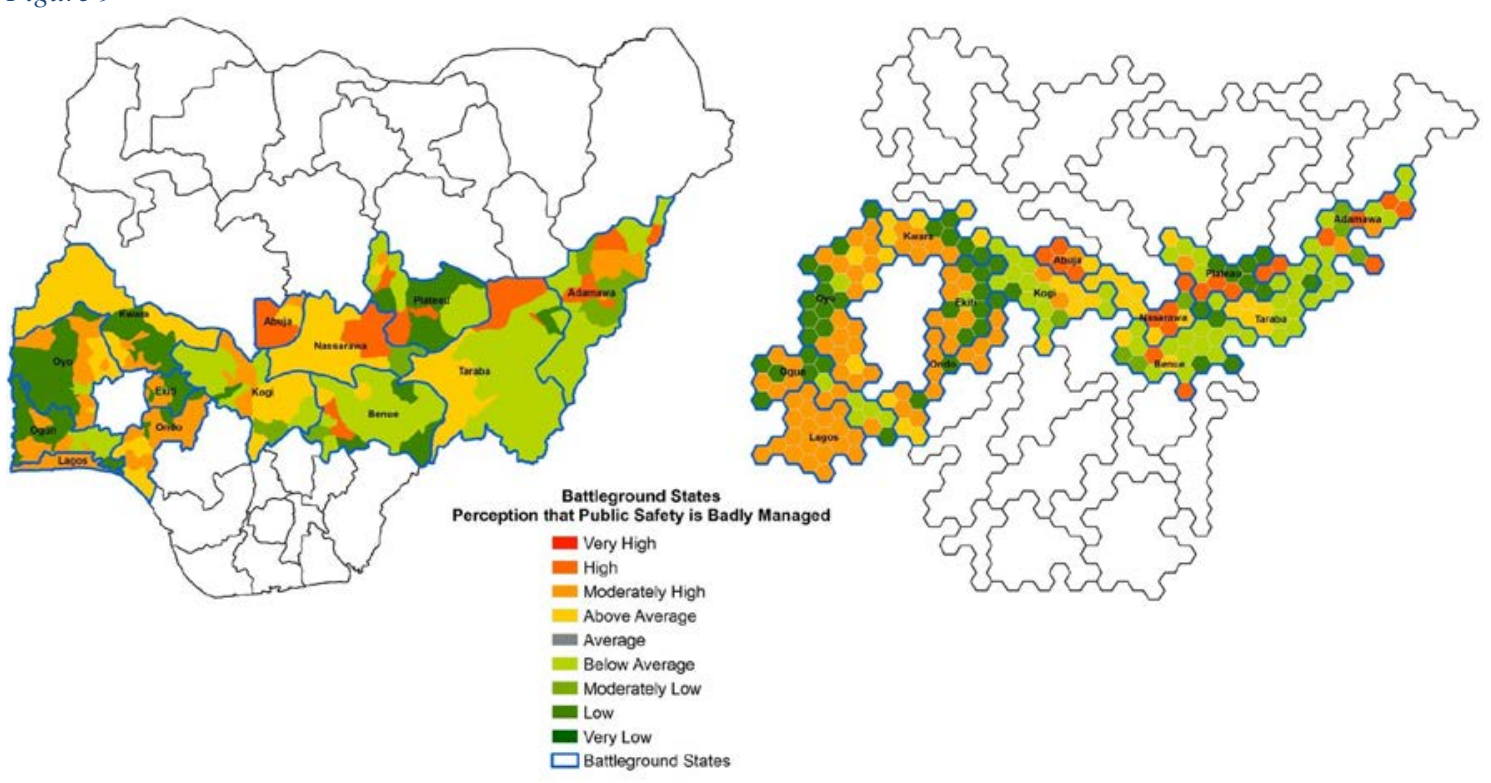

Figure 10

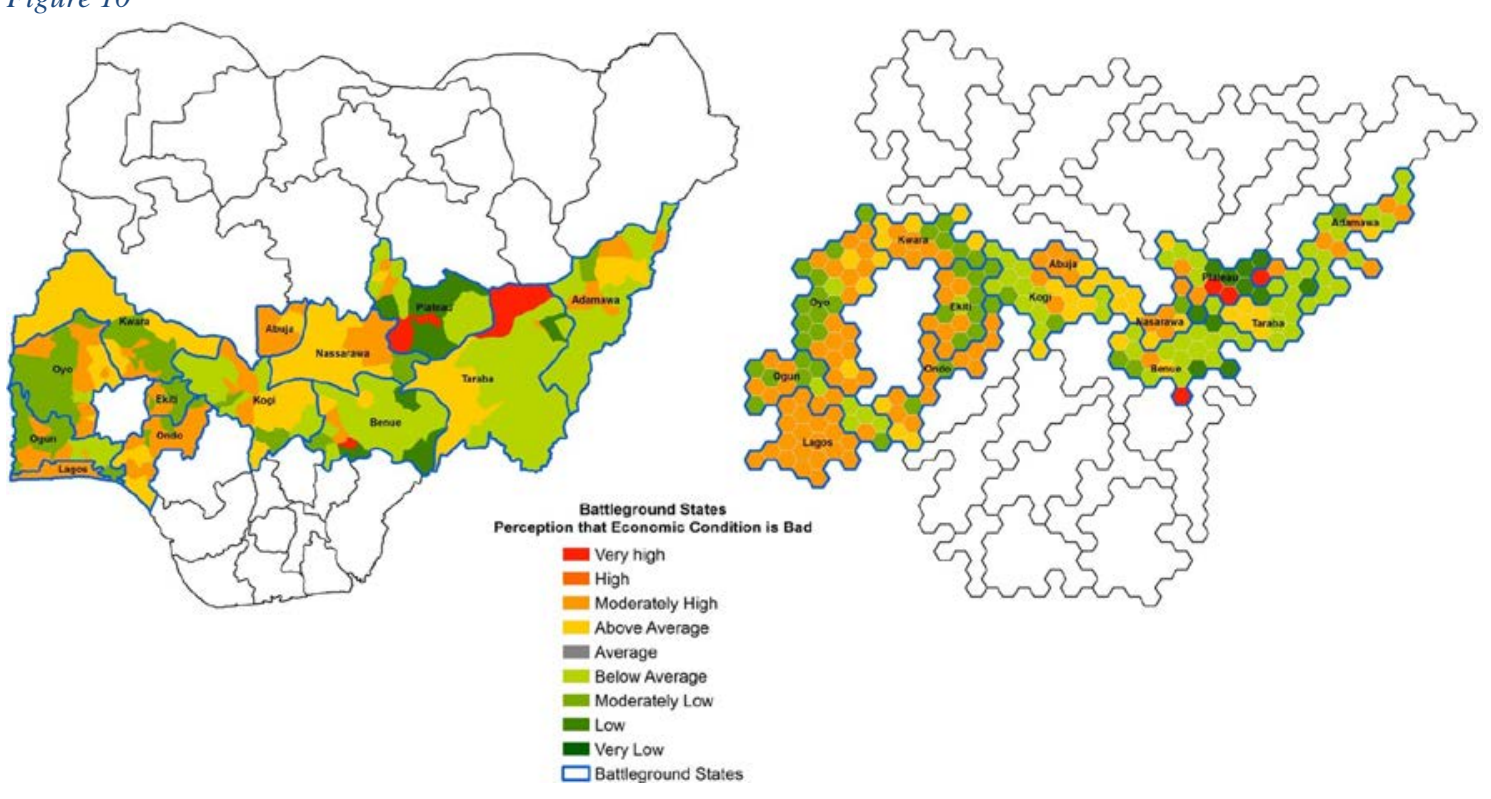


Figure 11

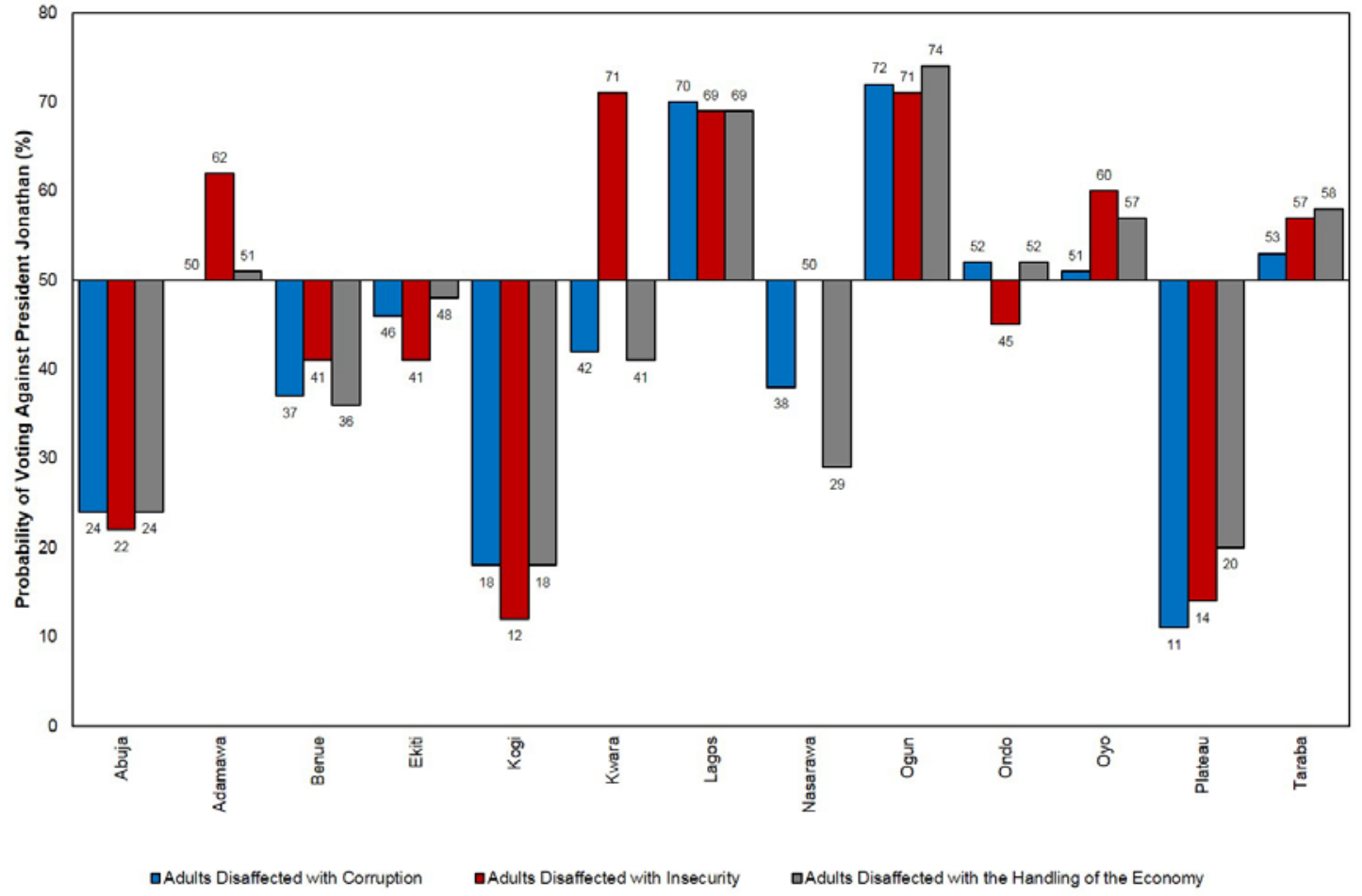

